See discussions, stats, and author profiles for this publication at: https://www.researchgate.net/publication/324616516

\title{
A long wavelength colourimetric chemosensor for fluoride
}

Article in Supramolecular Chemistry · April 2018

DOI: 10.1080/10610278.2018.1461873

CITATION

1

5 authors, including:

Luke Marchetti

National University of Ireland, Maynooth

1 PUBLICATION 1 CITATION

SEE PROFILE

(7) Robert B P Elmes

National University of Ireland, Maynooth

33 PUBLICATIONS 653 CITATIONS

SEE PROFILE

Some of the authors of this publication are also working on these related projects:

Study of Alkane $\sigma$-Complexes in Solid-State View project

PCcarbeneP pincer complex chemistry View project
48 PUBLICATIONS 752 CITATIONS

SEE PROFILE 


\section{Supramolecular Chemistry}

$=$

ISSN: 1061-0278 (Print) 1029-0478 (Online) Journal homepage: http://www.tandfonline.com/loi/gsch20

\section{A long wavelength colourimetric chemosensor for fluoride}

Luke A. Marchetti, Nan Mao, Tobias Krämer, Jonathan A. Kitchen \& Robert B.

P. Elmes

To cite this article: Luke A. Marchetti, Nan Mao, Tobias Krämer, Jonathan A. Kitchen \& Robert B. P. Elmes (2018): A long wavelength colourimetric chemosensor for fluoride, Supramolecular Chemistry

To link to this article: https://doi.org/10.1080/10610278.2018.1461873

View supplementary material $\widetilde{ }$

曲 Published online: 18 Apr 2018.

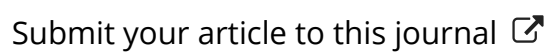

Q View related articles $\asymp$

View Crossmark data \lceil 


\title{
A long wavelength colourimetric chemosensor for fluoride
}

\author{
Luke A. Marchettia, Nan Mao ${ }^{\mathrm{a}}$, Tobias Krämer ${ }^{\mathrm{a}}$, Jonathan A. Kitchen ${ }^{\mathrm{b}, \mathrm{c}}$ and Robert B. P. Elmes ${ }^{\mathrm{a}}$ \\ aDepartment of Chemistry, Maynooth University, National University of Ireland, Maynooth, Ireland; ${ }^{b}$ Chemistry, University of Southampton, \\ Southampton, UK; ' ${ }^{C}$ Chemistry, Institute of Natural and Mathematical Sciences, Massey University, Auckland, New Zealand
}

\begin{abstract}
A family of chemosensors based on the squaramidoquinoxaline moiety (cyclobuta[b]quinoxaline1,2(3H,8H)-dione) (1-3) have been assembled by a simple room temperature one step synthesis. $\mathrm{X}$-ray crystallographic analysis of $\mathbf{2}$ demonstrated both strong hydrogen bond donor ability and tendency to $\pi$ stack in the solid state. Moreover, Compound $\mathbf{2}$, with its strongly electron withdrawing nitro-substituent, showed an obvious $\mathrm{F}^{-}$selective colour change (when measured against other halides) clearly visible to the naked eye from pink to green in DMSO solution. Further addition of $\mathrm{F}^{-}$led to a second colour change from green to yellow. Using TD-DFT, UV/Vis and NMR analysis we conclude that the observed colour changes are likely to be due to a two-step process involving two NH deprotonation steps. Colour changes of $\mathbf{1}$ and $\mathbf{3}$ were not as apparent in the presence of $\mathrm{F}^{-}$owing to the reduced acidity of the $\mathrm{NH}$ functionality of the squaramidoquinoxaline. The results of this study again demonstrate the use of squaramide derivatives as valuable building blocks in the field of anion recognition and demonstrate that the electron withdrawing aryl substituent is directly related to the sensing ability/acidity of the squaramide protons and can be used to tune their anion recognition behavior.
\end{abstract}

\section{ARTICLE HISTORY}

Received 5 September 2017

Accepted 15 March 2018

\section{KEYWORDS}

Anion sensing; squaramide; colorimetric; fluoride

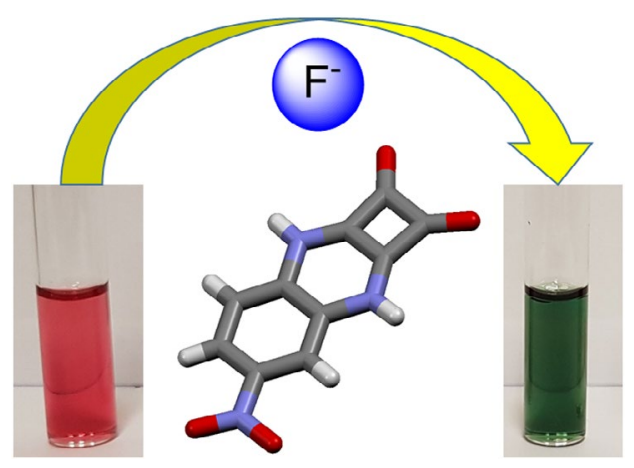

\section{Introduction}

From fluoride in our drinking water to chloride controlling electrical signalling in our brains, the ubiquity of anions in biology has meant that they play a pivotal role in daily life. This prevalence has led to widespread scientific interest in discrete molecules capable of binding, recognising and transporting anions (1-3). Indeed the field of anion recognition has emerged as a fundamental pillar of supramolecular chemistry with widespread interest across diverse areas of the chemical sciences with potential applications across biological, medical, environmental and industrial fields (4). Anion sensing in particular has garnered considerable research interest where the ability to selectively detect particular anions of interest, particularly those with an optical output, has been the subject of countless research articles (5-8). Very often such chemosensors are based on charge neutral receptor molecules that take advantage of strong hydrogen bond donating moieties such as ureas (9), thioureas $(10,11)$, thiosemicarbazides (12) and calixpyroles (13) to name just a few examples (14). More recently, we and others have taken advantage of a characteristically different family of receptors based around the squaramide motif (15-22). Squaramides with their inherent rigidity and strong hydrogen bond donor ability have proven themselves to be useful building blocks in supramolecular chemistry being used in the design of anion receptors (23-27), self-complementary molecular recognition motifs

CONTACT Robert B.P. Elmes robert.elmes@mu.ie

(4) The Supplemental data for this article can be accessed at https://doi.org/10.1080/10610278.2018.1461873.

(c) 2018 Informa UK Limited, trading as Taylor \& Francis Group 

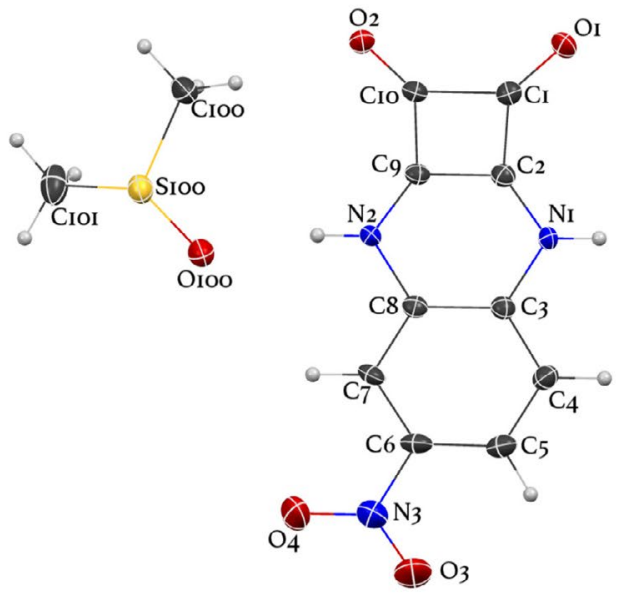
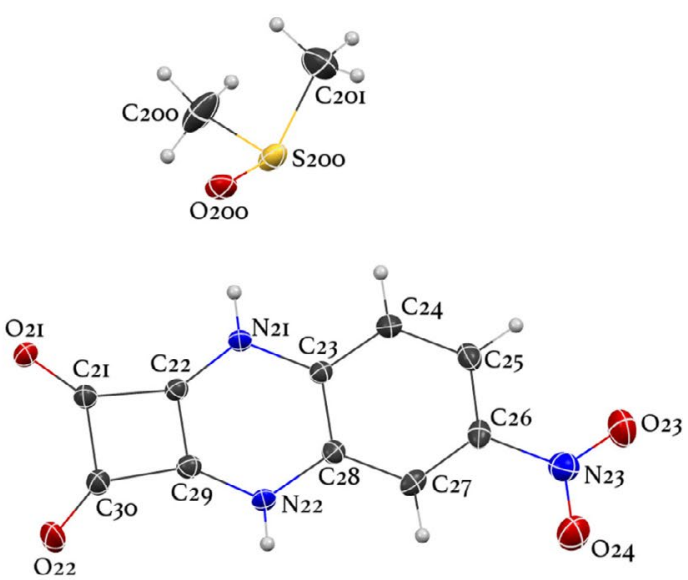

Figure 1. (Colour online) Molecular structure of 2.DMSO with thermal elipsoids set at 50\%.

(28), and many organocatalysts (29). Given our interest in the squaramide motif and the synthetic versatility of the ethyl squarate building block $\mathbf{7}$ we wished to develop further structural motifs suitable for anion recognition and sensing. We envisaged that by condensation of $\mathbf{7}$ with a suitable diaminobenzene starting material we could create a novel squaramide motif, cyclobuta[b]quinoxaline-1, $2(3 \mathrm{H}, 8 \mathrm{H})$-dione or'squaramidoquinoxaline' (Scheme 1). We expected that by modification of a parent squaramidoquinoxaline scaffold with either electron withdrawing or electron donating groups we could modulate the acidities of the $\mathrm{NHs}$ of the squaramide thereby provide a level of control over the selectivity of any anion recognition process that may occur. Described herein are our efforts to synthesise 1-3 bearing both electron withdrawing and electron donating substituents as well as an evaluation of their anion sensing behaviour using a combination of both UV/Vis and NMR spectroscopy.

\section{Results and discussion}

\section{Receptor design and synthesis}

We chose to pursue the synthesis of 1-3 where we expected variation of the substitution pattern around C- 5 would have a profound effect on the acidity of the $\mathrm{NH}$ protons and thus allow us to 'tune' their response to various anionic halides.

The synthesis of 1-3 was carried out using our previously reported synthesis of squaramides by the reaction of the appropriate diamine (4-6) with diethyl squarate $\mathbf{7}$ in ethanol to afford 1-3 in 64, 74 and $97 \%$ yield, respectively (Scheme 1) (16). Compounds $\mathbf{1 - 3}$ were fully characterised using ${ }^{1} \mathrm{H}$ NMR, ${ }^{13} \mathrm{C} \mathrm{NMR}$, IR, UV/vis and mass spectrometry.
All spectroscopic data was consistent with the formation of the desired compounds (See Supporting Information).

Additionally, small red block-like crystals of 2.DMSO were grown by slow evaporation of a DMSO solution and the low temperature $(100 \mathrm{~K})$ molecular structure determined (Figure 1). 2.DMSO crystallised in the triclinic space group $P-1$ and contained two crystallographically independent molecules of $\mathbf{2}$ in the asymmetric unit as well as two interstitial DMSO molecules (Figure 1) that form strong hydrogen bonds to one of the $\mathrm{NH}$ groups of each independent molecule [N2 $\cdots 0100=2.742(4) \AA$ and $<(\mathrm{NH} \cdots \mathrm{O})=171^{\circ} ; \mathrm{N} 21 \cdots \mathrm{O} 200=2.728(4) \AA$ and $<(\mathrm{NH} \cdots \mathrm{O})$ $=176^{\circ}$.

The structure exhibits some interesting packing interactions that involve classic hydrogen bonding, weaker non-classical $\mathrm{CH}$-based hydrogen bonding and $\pi \cdots \pi$ stacking. $\mathrm{NH}$ and $\mathrm{CH}$-based hydrogen bonding between neighbouring molecules of 2 results in a hydrogen bonded zig-zag chain (Figure 2) where the squaramide oxygen atoms form $\mathrm{H}$-bonding interactions to the $\mathrm{NH}$ and $\mathrm{CH}$ groups on a neighbouring molecule $[\mathrm{N} 1 \cdots \mathrm{O} 21=2.783(4)$ $\AA$ and $<(\mathrm{NH} \cdots \mathrm{O})=170^{\circ} ; \mathrm{C} 4 \cdots \mathrm{O} 22=3.248(5) \AA$ and $<(\mathrm{CH} \cdots \mathrm{O})=171^{\circ} ; \mathrm{N} 22 \ldots \mathrm{O} 2=2.806 \AA$ and $<(\mathrm{NH} \cdots \mathrm{O})=161^{\circ}$; $\mathrm{C} 27 \ldots \mathrm{O} 1=3.240(5) \AA$ and $<(\mathrm{CH} \cdots \mathrm{O})=173^{\circ}$ ] (Figure 2). This propagates throughout the structure to give the overall $\mathrm{H}$-bonded zig-zag chain. These chains are further linked into sheets via weaker $\mathrm{CH}$-based hydrogen bonds between the oxygen atoms of the nitro group and neighbouring $\mathrm{CH}$ group $\left[\mathrm{C} 25 \cdots \mathrm{O} 3=3.360(5) \AA\right.$ and $\left.<(\mathrm{CH} \cdots \mathrm{O})=165^{\circ}\right]$ (Figure 3 ). The sheets of $\mathbf{2}$ are finally arranged into layers through $\pi \cdots \pi$ stacking interactions [inter centroid distances $\sim 3.5$ Å] between adjacent aromatic groups to give an overall layered topology (Figure 3). 
(A)

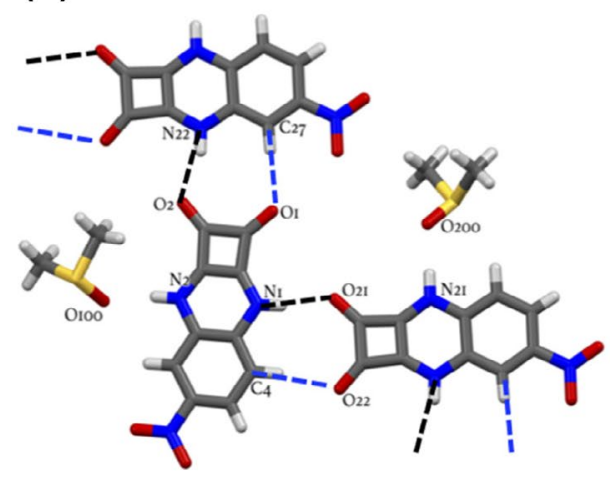

(B)

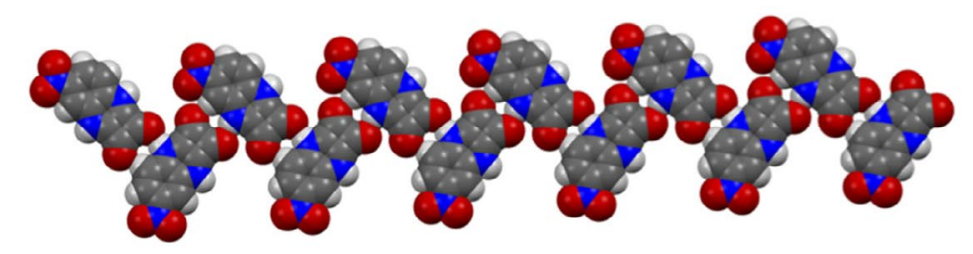

Figure 2. (Colour online) Hydrogen bonding interactions in 2.DMSO that result in the formation of the zig-zag chain (A) $\left[\mathrm{N} 1 \cdots 021=2.783(4) \AA\right.$ and $<(\mathrm{NH} \cdots \mathrm{O})=170^{\circ} ; \mathrm{C} 4 \cdots \mathrm{O} 22=3.248(5) \AA$ and $<(\mathrm{CH} \cdots \mathrm{O})=171^{\circ} ; \mathrm{N} 22 \cdots 02=2.806 \AA$ and $<(\mathrm{NH} \cdots \mathrm{O})=161^{\circ}$; $\mathrm{C} 27 \cdots 01=3.240(5) \AA$ and $\left.<(\mathrm{CH} \cdots \mathrm{O})=173^{\circ}\right]$; and space filling representation showing the long range ordering of the zig-zag $\mathrm{H}$-bonded chain (B).

(A)

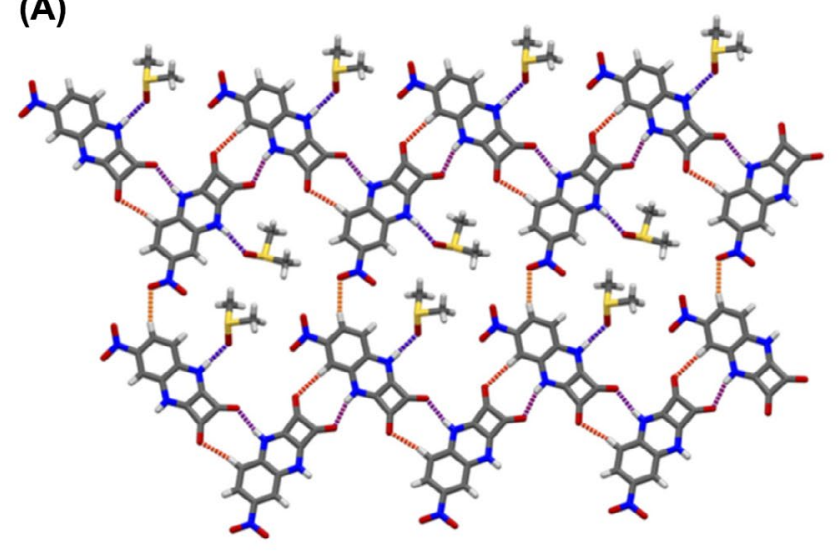

(B)

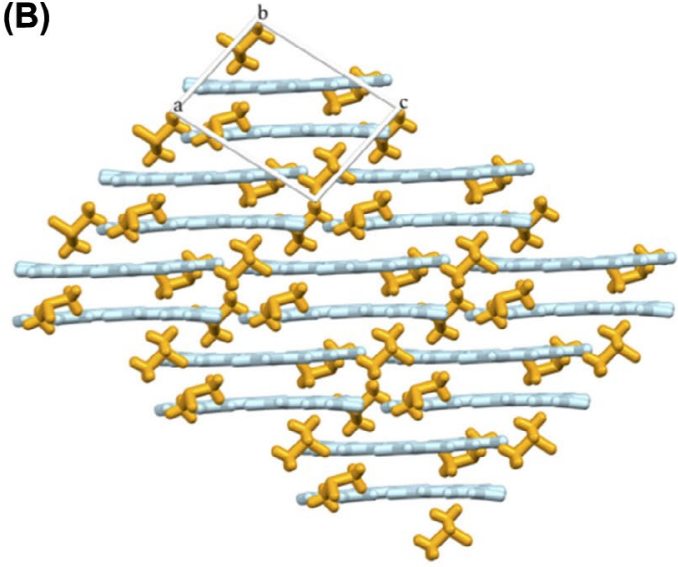

Figure 3. (Colour online) All H-bonding interactions present in the formation of the 2D sheets of $2(\mathrm{~A})$ - purple dashed lines are NH-based $\mathrm{H}$-bonds and orange dashed lines are $\mathrm{CH}$-based H-bonds. View of the $\pi$-stacked layers formed between the 2D sheets (B) of 2 (in blue) and the dispersion of interstitial DMSO molecules (in orange) throughout the layered structure.

\section{UV/Vis absorption properties}

In $0.5 \% \mathrm{H}_{2} \mathrm{O}$ in DMSO solution the absorption spectra of sensors $\mathbf{1}$ and $\mathbf{3}$ gave rise to broad bands centred at 312 and $347 \mathrm{~nm}$ for $\mathbf{1}$ and 320 and $354 \mathrm{~nm}$ for $\mathbf{3}$ attributed in both cases to $\pi-\pi^{*}$ transitions, respectively. The spectrum of 2 also showed strong $\pi-\pi^{*}$ absorption bands at 310 and $390 \mathrm{~nm}$ respectively with an additional broad shoulder centred at $532 \mathrm{~nm}$ ascribed to a charge transfer within the molecule owing to the presence of the electron withdrawing nitro group.(30) An additional long wavelength shoulder at $715 \mathrm{~nm}$ was also observed. Addition of $1 \%$ acetic acid to a dilute solution of $\mathbf{2}(10 \mu \mathrm{M})$ in $0.5 \% \mathrm{H}_{2} \mathrm{O}$ in DMSO caused the disappearance of the absorption band at $715 \mathrm{~nm}$ and an increase in absorbance of the bands at 310, 390 and $532 \mathrm{~nm}$ but did not result in any observable colour change. Conversely, addition of $1 \%$ triethylamine caused an increase in the absorbance of the bands at 715 and
$450 \mathrm{~nm}$ and was concomitant with a stark colour change from pink to green clearly visible to the naked eye (See Supporting Information). Insight into the experimentally observed UV-vis spectral changes was gained from TD-DFT calculations at the SMD-PCM/B3LYP/6-311G+(2p,d) level of theory. The calculated absorption spectrum of $\mathbf{2}$ is in very good agreement with experiment, with three peaks predicted at 301,382 and $549 \mathrm{~nm}$. The $\pi-\pi^{*}$ type character of these transitions is revealed by analysis of the associated Natural Transition Orbitals (NTO). In contrast to analysis of excitation amplitudes in the canonical molecular orbital basis, NTOs provide an easy means to interpret the character of electronic transitions. The low-energy peak at $549 \mathrm{~nm}$ corresponds to the HOMO-LUMO transition, which is dominated by an intramolecular charge-transfer process between the squaramide ring system and the nitro group (Figure 4). The nature of the other two transitions can be readily identified from the NTO plots. Single deprotonation 


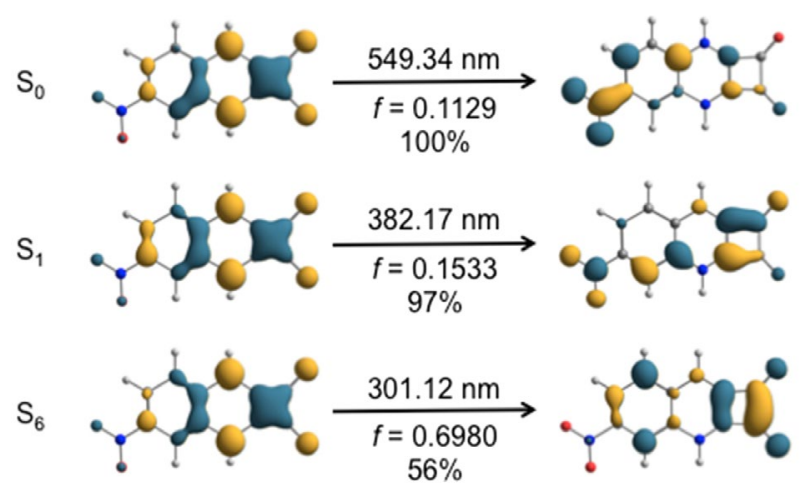

Figure 4. (Colour online) Plots of NTOs (isovalue $=0.05$ ) for key electronic transitions in 2. Excitation energies are given along with oscillator strengths and weights of NTO pairs.

of $\mathbf{2}$ causes a red-shift of the peak at $549 \mathrm{~nm}$, irrespective of which tautomeric form of [2-H]- is considered (see ESI). Calculated peaks at 653 and $730 \mathrm{~nm}$ for tautomer N1 and $\mathrm{N} 2$, respectively, are consistent with a reduced HOMOLUMO gap for these anionic species. Likewise, the peak at $382 \mathrm{~nm}$ in $\mathbf{2}$ is shifted to around $420 \mathrm{~nm}$ in both tautomers. In summary, the calculations further indicate that the characteristic red-shift in the presence of base is due to single deprotonation of $\mathbf{2}$. It should be noted that a linear energy scale for comparison between experimental and theoretical excitation energies is more convenient, and in the present case the deviation is $0.03-0.20 \mathrm{eV}$. Since these values fall into the common error range for TD-DFT,(31) it is not possible to discriminate between the two tautomeric forms of [2-H] based on their calculated UV/Vis spectra.

Combined, the above results suggest that in solution a proportion of $\mathbf{2}$ may exist in its mono-deprotonated form (Scheme 2) even in the absence of base. This effect has previously been reported by Taylor and co-workers for squaramide systems containing strongly electron withdrawing aryl substituents and is thought to be favoured due to the possibility of delocalisation of the formal negative charge in to the cyclobutenedione ring (24). To further investigate this observation, a $\mathrm{pH}$-spectrophotometric titration in a mixture of acetonitrile/water $(9 / 1 \mathrm{v} / \mathrm{v}$; in the presence of $0.1 \mathrm{M} \mathrm{TBAPF}_{6}$ ) was undertaken as described previously $(17,19)$. While the UV/Vis absorption spectrum under these conditions was significantly shifted, $\mathbf{2}$ appeared to undergo two distinct deprotonation events observed initially as a hypochromism centred at 390 and $500 \mathrm{~nm}$ and a concomitant hyperchromism at 415 and $615 \mathrm{~nm}$ between $\mathrm{pH} \approx 6-9.5$. This was followed by a second spectral change between $\mathrm{pH} \approx 10.3-12$ in which hypochromism across the entire spectrum was observed. The spectral changes were again seen as colour changes to the naked eye from pink to green to yellow. While the pink - green colour change (1st deprotonation step) is reversible by addition a protic solvent, the green - yellow (2nd deprotonation step) cannot be reversed and it appears that the di-deprotonated derivative undergoes a time-dependent fragmentation. The $\mathrm{pK}_{\mathrm{a}}$ titration profile is shown in Figure 5. The obtained pKa value for the first deprotonation was determined as $8.25( \pm 0.03)$ however a pKa value for the di-deprotonated derivative could not be determined due to its instability at $\mathrm{pH}$ values below 12 evidenced by further time dependent spectral changes occurring at high $\mathrm{pH}$ values.

\section{UV/Vis absorption anion titrations}

Given the distinct colour changes observed above with 2, we next wished to explore its potential as a colorimetric anion sensor where, with the enhanced acidity afforded by the nitro group, we expected that this compound may give rise to a selective sensor for $\mathrm{F}^{-}$; the most basic of the halides. We evaluated the ability of $\mathbf{1 - 3}$ to detect halides in $0.5 \% \mathrm{H}_{2} \mathrm{O}$ in DMSO solution by titration of $\mathrm{F}^{-}, \mathrm{Cl}^{-}, \mathrm{Br}^{-}$ and $\mathrm{I}^{-}$as their tetrabutylammonium salts $\left(\mathrm{TBA}^{+}\right)$, observing any changes in their ground state properties. As expected, the most dramatic effects were observed upon addition of $\mathrm{F}^{-}$to $\mathbf{2}$ whereby the solution underwent a distinct colour change from pink to green (similar to that observed upon addition of $\mathrm{Et}_{3} \mathrm{~N}$ ). The absorption at $310 \mathrm{~nm}$ underwent a red shift to $324 \mathrm{~nm}$ and, along with the bands at 390 and $532 \mathrm{~nm}$, experienced a strong hypochromic effect concomitant with the formation of a new band centred at $540 \mathrm{~nm}$ and a strong increase in the shoulder at $715 \mathrm{~nm}$ (Figure 6). Formation of four isosbestic points at 364, 416, 484 and $597 \mathrm{~nm}$ were also clearly observed suggesting that only two species coexist at this equilibrium. However, it appears that the interaction of $\mathrm{F}^{-}$with $\mathbf{2}$ takes place according to two well-defined steps, where further addition of $\mathrm{F}^{-}$resulted in the intensity of the bands centred at 324,540 and $715 \mathrm{~nm}$ to rapidly decrease. We suggest from these results that upon addition of low concentrations of $\mathrm{F}^{-}$, a distinct redshift of the charge-transfer bands results from the first deprotonation of $\mathbf{2}[\mathbf{2}-\mathrm{H}]^{-}$, however, subsequent addition of excess $\mathrm{F}^{-}$leads to a second deprotonation of the squaramide $\mathrm{NH}$ proton $[2-2 \mathrm{H}]^{2-}$ and a second colour change from green to yellow. Such behaviour has previously been observed with urea (32) and squaramide derivatives containing electron-withdrawing substituents $(16,24)$. Moreover, the results obtained in the pH-spectrophotometric titration above clearly support these observations. Treatment of $\mathbf{2}$ with $\mathrm{Cl}^{-}, \mathrm{Br}^{-}$and I- resulted in comparatively minor changes, however, the addition of each of these anions did result in absorbance increases at 715 and $450 \mathrm{~nm}$ suggesting that the presence of $\mathrm{Cl}^{-}$, $\mathrm{Br}^{-}$and $\mathrm{I}^{-}$may promote the mono-deprotonation of $\mathbf{2}$ in DMSO solution (Figure 7). Interestingly, the addition of these anions did not result in any observable colour 


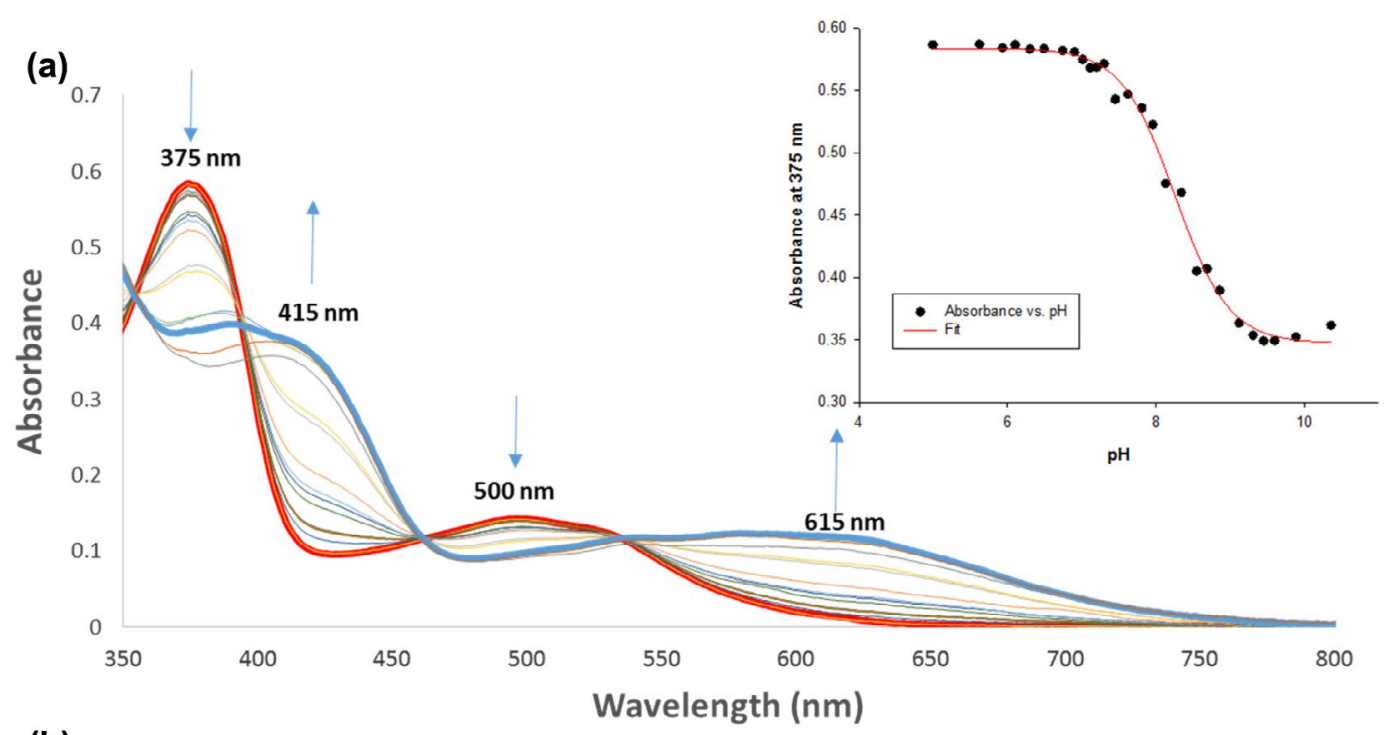

(b)

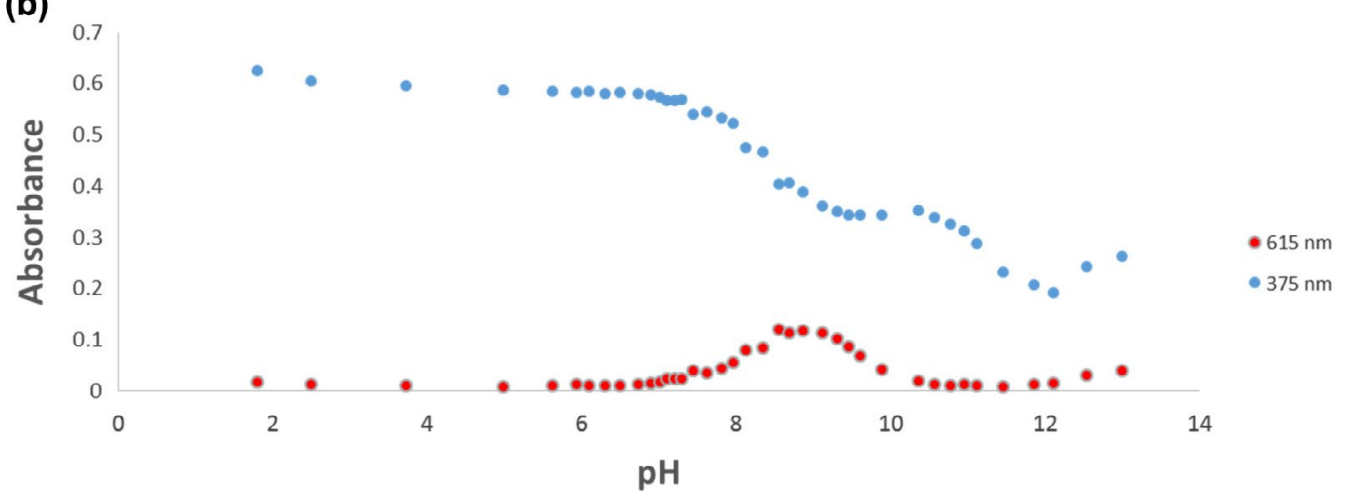

Figure 5. (Colour online) (a) Absorption spectra taken over the course of the $\mathrm{pH}$-spectrophotometric titration of $2\left(1 \times 10^{-5} \mathrm{M}\right)$ from $\mathrm{pH}$ $\approx 6-9$ in an acetonitrile-water mixture (9/1 v/v; in presence of $0.1 \mathrm{M} \mathrm{TBAPF}_{6}$ ). (Inset): Four parameter sigmoid curve fit with the point of inflexion corresponding to the pKa value (b) Plots of absorbance vs. $\mathrm{pH}$ at $375 \mathrm{~nm}$ and $615 \mathrm{~nm}$ showing two distinct deprotonation events from $\mathrm{pH} 2-\mathrm{pH} 13$.

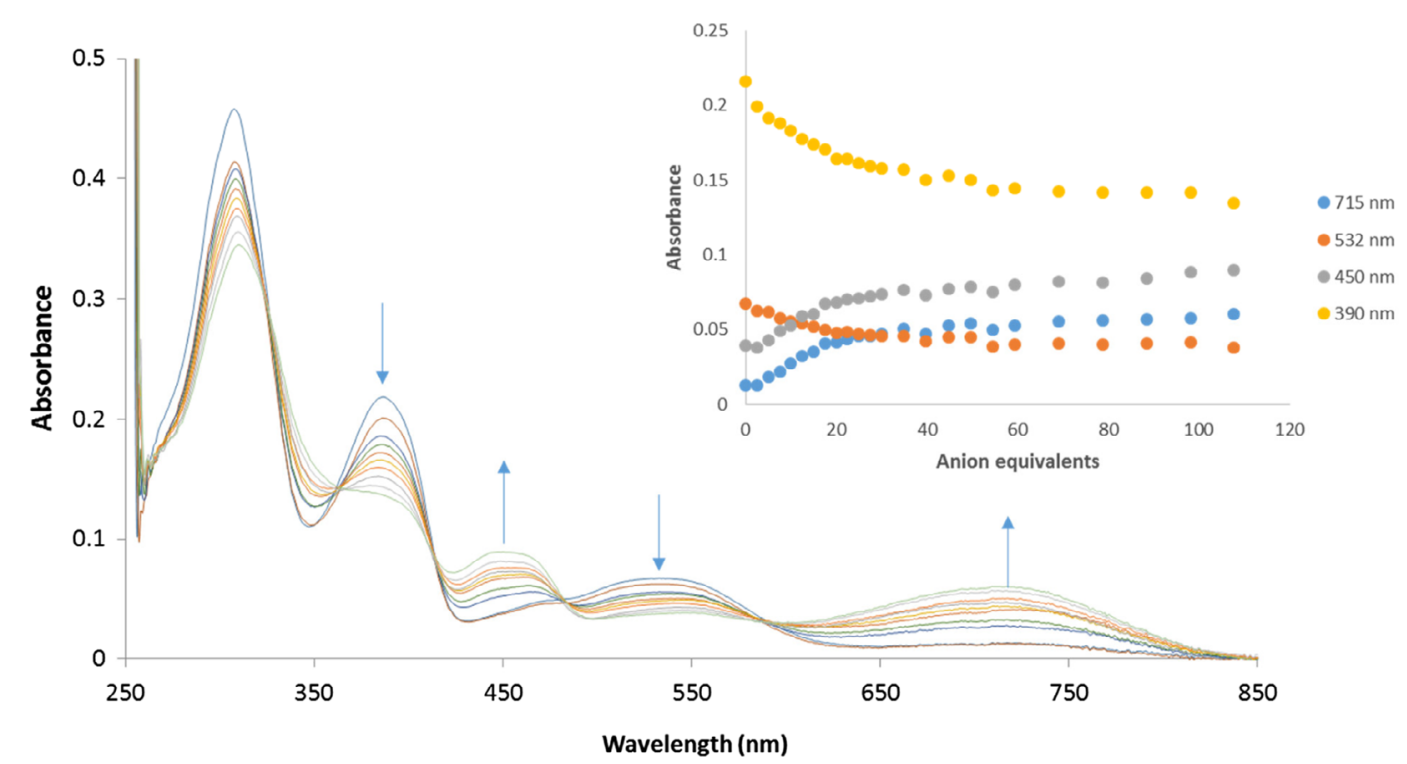

Figure 6. (Colour online) Changes observed in the absorption spectrum of $2\left(1 \times 10^{-5} \mathrm{M}\right)$ upon addition of TBAF $(0-0.07 \mathrm{mM})$ in $0.5 \% \mathrm{H}_{2} \mathrm{O}$ in DMSO solution. (Inset): Absorbance changes observed at 715, 532, 450 and $390 \mathrm{~nm}$. 


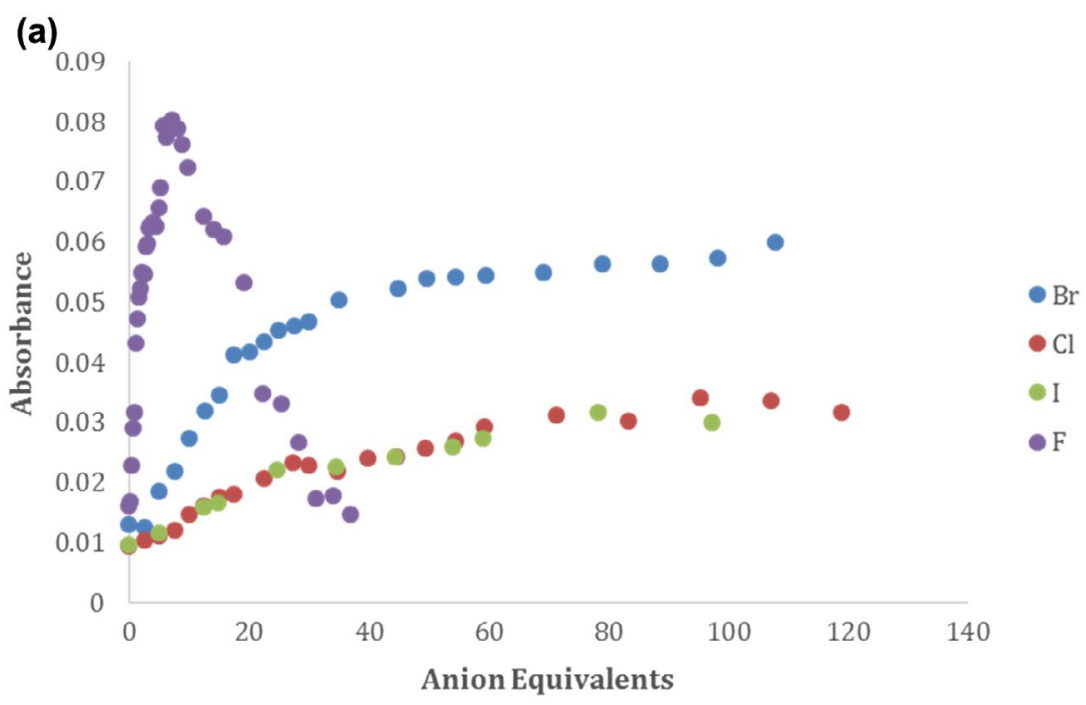

(b)

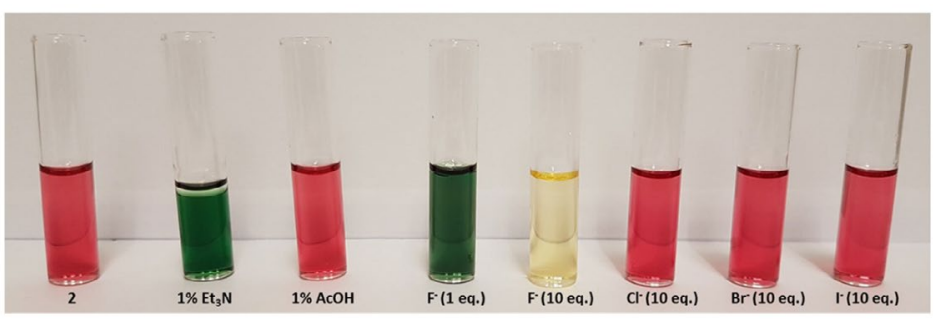

Figure 7. (Colour online) (a) Comparison of the absorbance changes observed at $715 \mathrm{~nm}$ upon addition of TBAF (0-0.37 mM), TBAI $(0-1.1 \mathrm{mM}), \operatorname{TBACl}(0-1.2 \mathrm{mM})$ and $\operatorname{TBABr}(0-1.1 \mathrm{mM})$ to a solution of $2\left(1 \times 10^{-5} \mathrm{M}\right)$ in $0.5 \% \mathrm{H}_{2} \mathrm{O}$ in DMSO solution. (b) Colourimetric changes observed for $2\left(1 \times 10^{-3} \mathrm{M}\right)$ under acidic conditions, basic conditions and in the presence of various halides in DMSO at $25^{\circ} \mathrm{C}$.

change of the solution. Addition of more basic oxoanions $\left(\mathrm{H}_{2} \mathrm{PO}_{4}^{-}, \mathrm{SO}_{4}^{2-}, \mathrm{CH}_{3} \mathrm{COO}^{-}\right)$gave similar results to that of $\mathrm{F}^{-}$ where a colour change from pink to green was observed further confirming the propensity of basic anions to deprotonate sensor 2. From the observed changes in the UVvis absorption studies, the association constants of $\mathbf{2}$ with the different halides were estimated using global curve fitting analysis (BindFit software).(33, 34) Curves were fitted to the absorption data at $715,532,450$ and $390 \mathrm{~nm}$ in each case according to a 1:1 binding model. From these titrations we estimated association constants for $\mathbf{2}$ to be $23262 \mathrm{M}^{-1}$ (error = 3.67\%), $5835 \mathrm{M}^{-1}$ (error $=3.67 \%$ ), $4323 \mathrm{M}^{-1}$ (error $=12 \%$ ), and $2257 \mathrm{M}^{-1}$ (error $=4.86 \%$ ) for $\mathrm{F}^{-}$, $\mathrm{Br}^{-}, \mathrm{I}^{-}$and $\mathrm{Cl}^{-}$, respectively (See Supporting Information).

When these measurements were repeated using 3, which lacks an electron withdrawing substituent, the changes in the absorption spectrum were comparably minor upon addition of $\mathrm{F}^{-}, \mathrm{Cl}^{-}, \mathrm{Br}^{-}$and $\mathrm{I}^{-}$. The addition of $\mathrm{F}^{-}$did give rise to an additional absorption centred at $387 \mathrm{~nm}$ which upon subsequent additions disappeared (see Supporting Information). This culminated in a change in colour of the solution from a pale orange to a slightly darker orange. Similarly, 1 showed comparatively minor changes in colour upon addition of $\mathrm{F}^{-}$, going from yellow to a darker shade of yellow and showed no observable response to $\mathrm{Cl}^{-}, \mathrm{Br}^{-}$and $\mathrm{I}^{-}$. Given that the spectroscopic behaviour of $\mathbf{1}$ has recently been studied by Niu et al. we did not pursue this line of experiments (35).

\section{H NMR anion titrations}

In order to provide further support of our observations in the UV/Vis titrations we undertook ${ }^{1} \mathrm{H}$ NMR studies of 2 in $0.5 \% \mathrm{H}_{2} \mathrm{O}$ in DMSO- $d 6$ solution. Interestingly, only minor changes were observed in the presence of $\mathrm{Cl}^{-}, \mathrm{Br}^{-}$ and $\mathrm{I}^{-}$suggesting that little interaction of these anions is occurring with $\mathbf{2}$ and that the observed UV/Vis spectroscopic changes must be related to a small increase in the propensity of $\mathbf{2}$ to become mono-deprotonated. We had expected that the acidity of the squaramide $\mathrm{NH}$ protons may have yielded a strong hydrogen bond donating group to interact with the halides, in particular with $\mathrm{Cl}^{-}$ which is known to bind to the conventional squaramide moiety containing electron withdrawing aryl substituents (16). However, in this case, only a very minor downfield shift of the NH signal, coupled with some peak broadening was observed, suggesting that $\mathrm{Cl}^{-}, \mathrm{Br}^{-}$and $\mathrm{I}^{-}$are not binding to $\mathbf{2}$ to any meaningful extent. In the presence 


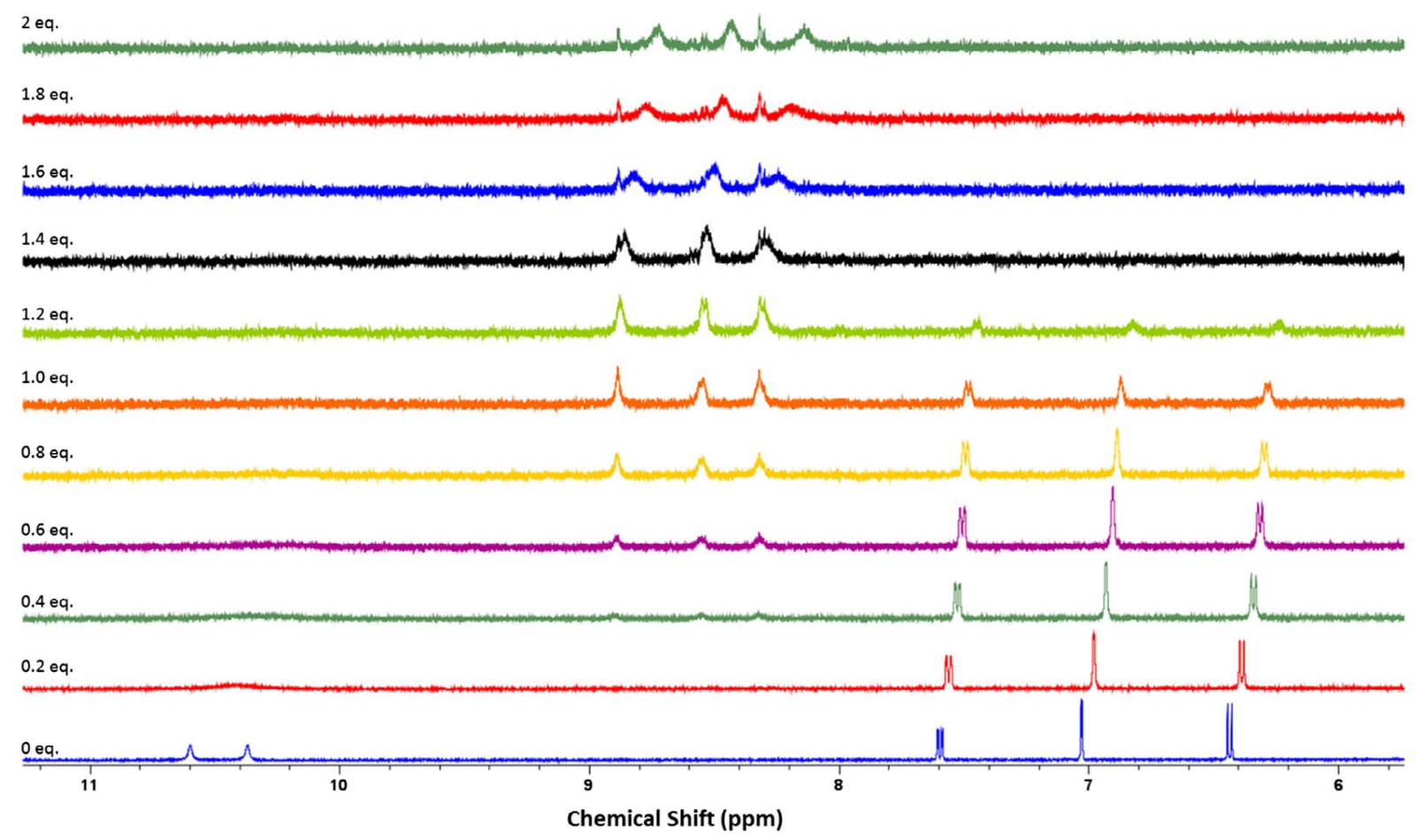

Figure 8. (Colour online) Stack plot of ${ }^{1} \mathrm{H}$ NMR spectra of $2\left(2.5 \times 10^{-3} \mathrm{M}\right)$ upon addition of TBAF $(0-2$ equiv. $)$ in DMSO- $d_{6}$ at $25^{\circ} \mathrm{C}$.

of $\mathrm{F}^{-}$a considerably more complicated behaviour was observed whereby initial additions of $\mathrm{F}^{-}(0-0.6$ eq.) resulted in a large degree of peak broadening observed for the NH signals and a significant upfield shift of all three aromatic signals. As proposed in the previous section we ascribe this initial behaviour to acid-base interactions with $\mathrm{F}^{-}$. Subsequent additions of $\mathrm{F}^{-}$again resulted in a second distinct process occurring where three new peaks evolved at 8.3, 8.5 and $8.9 \mathrm{ppm}$ at the same time as the original aromatic peaks disappeared. Again, this process was concomitant with an original colour change from pink to green followed by a second change from green to yellow. We suggest again that this behaviour can be explained by the occurrence of a second deprotonation event being triggered by the presence of excess $\mathrm{F}^{-}$. The representative spectra for titration of $\mathbf{2}$ with $\mathrm{F}^{-}$is shown in Figure 8, illustrating the significant broadening of the squaramide proton signals and the subsequent spectral changes upon addition of increasing $\mathrm{F}^{-}$. Furthermore, upon the addition of 5 equivalents of TBAF to a solution of $\mathbf{2}$ in DMSO- $\mathrm{d}_{6^{\prime}}$, the formation of a triplet at $16.2 \mathrm{ppm}$ in the ${ }^{1} \mathrm{H}$ spectrum was also clearly observed confirming the formation of $\mathrm{HF}_{2}^{-}$; a product of the acid/base reaction between $\mathbf{2}$ and TBAF (36).

\section{Application of 2 towards F- test strips}

Having studied the anion sensing mechanism of $\mathbf{2}$ in detail, we next wished to evaluate its potential as a sensor for

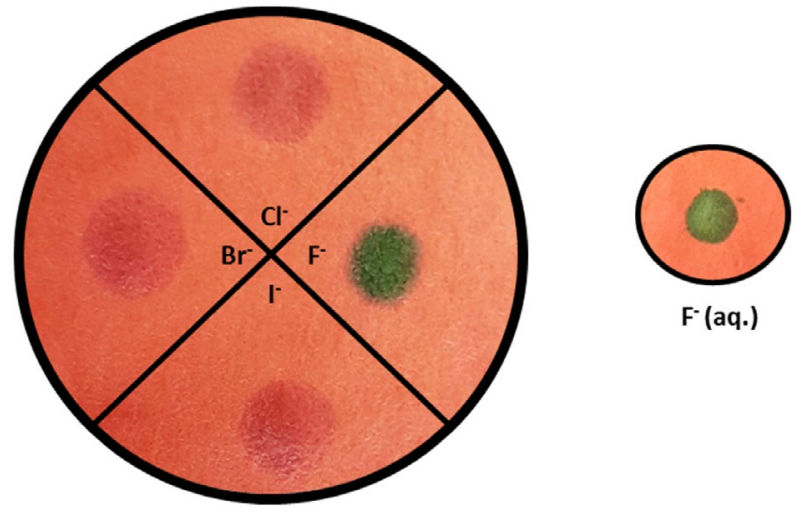

Figure 9. (Colour online) Photograph of filter paper impregrated with $2(40.7 \mathrm{mM})$ and the colorimetric response observed upon addition of $2 \mu \mathrm{L}$ of (a) TBAF, TBACl, TBABr and TBAI $(0.445 \mathrm{M})$ in DMSO and (b) TBAF (0.445 M) in $\mathrm{H}_{2} \mathrm{O}$ after gentle drying.

$\mathrm{F}^{-}$with real life application. Test strips of $\mathbf{2}$ were prepared by immersing filter papers into a DMSO solution of $\mathbf{2}$ $(40.7 \mathrm{mM})$ before allowing the strips to dry fully in an oven $\left(60^{\circ}\right.$ for $\left.12 \mathrm{hrs}\right)$. The test strips containing 2 were then used to demonstrate the applicability of this molecule towards halide sensing. Figure 9 shows photographs of the test strips after additions of $2 \mu \mathrm{L}$ of DMSO solutions of TBAF, TBACl, TBABr and TBAI (0.445 M). Upon addition of TBAF the colour was observed to change instantly from pink to green while the areas of the filter paper treated with the other halides were shown to remain unchanged. These tests were also carried out at $\mathrm{pH}$ values ranging from $\mathrm{pH}$ 


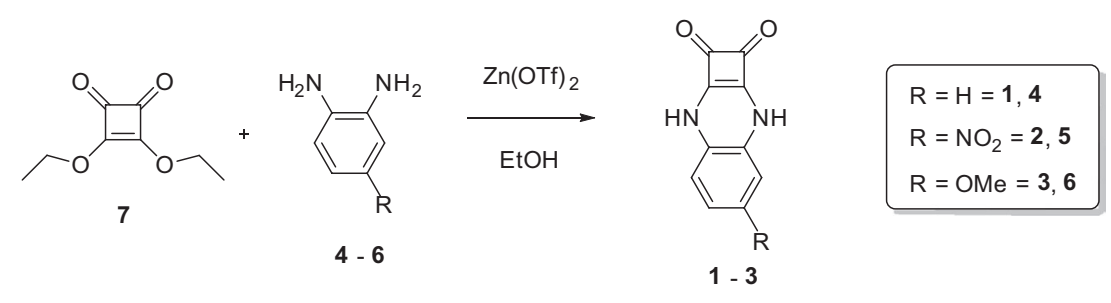

Scheme 1. Synthesis of squaramidoquinoxalines 1-3.

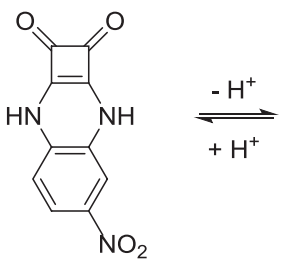

2

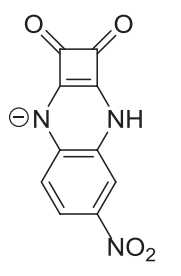

$[2-\mathrm{H}]^{-}$

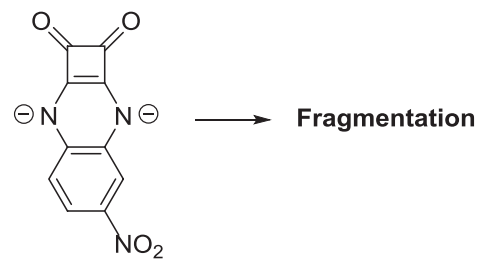

$[2-2 \mathrm{H}]^{2-}$

Scheme 2. (Colour online) Proposed acid-base behaviour and corresponding colorimetric response of 2.

5 to $\mathrm{pH} 8$ and in all cases $\mathbf{2}$ was capable of sensing the presence of $\mathrm{F}^{-}$. Additionally, when an aqueous solution of TBAF $(0.445 \mathrm{M})$ was also added, followed by gentle heating, the colour was again observed to change instantly from pink to green clearly demonstrating the practical use of this very simple sensor molecule to the analysis of aqueous solutions containing $\mathrm{F}^{-}$.

\section{Conclusions}

In conclusion, we have reported the synthesis of a family of chemosensors 1-3 based on the 'squaramidoquinoxaline' moiety where the new structures have been characterized by a combination of NMR spectroscopy and, where possible, X-ray crystallography. We have described their UV/Vis absorption properties where compound $\mathbf{2}$ was shown to display a characteristic long wavelength absorption at $715 \mathrm{~nm}$. The halide recognition abilities of the receptors were also investigated where $\mathbf{2}$ was shown to undergo drastic colorimetric changes from pink to green upon titration with $\mathrm{F}^{-}$which culminated in a large increase in absorption at $715 \mathrm{~nm}$ suggesting the existence of a deprotonation event. Further addition of $\mathrm{F}^{-}$led to a second colour change from green to yellow and a concomitant reduction of all absorption bands in the UV/Vis absorption spectrum. The $\mathrm{NO}_{2}$ derivative 2 was also found to be a selective colourimetric sensor for $\mathrm{F}^{-}$where no such changes were observed in the presence of the other halides $\mathrm{Cl}^{-}, \mathrm{Br}^{-}$or I-. Using UV/Vis, NMR and TD-DFT analysis we conclude that the observed colour changes are likely to be due to a two-step process involving two $\mathrm{NH}$ deprotonation steps. Colour changes of $\mathbf{1}$ and
3 were not as apparent in the presence of $\mathrm{F}^{-}$owing to the reduced acidity of the $\mathrm{NH}$ functionality of the squaramidoquinoxaline and the apparent lack of an electron withdrawing group that allows for charge transfer within the molecule. The application of $\mathbf{2}$ towards $\mathrm{F}^{-}$sensing was also demonstrated using a test strip method where addition of TBAF caused the colour of a filter paper impregnated with 2 to change instantly from pink to green while areas treated with the other halides were shown to remain unchanged.

The results of this study again demonstrate the use of squaramide derivatives as valuable building blocks in the field of anion recognition and sensing and demonstrate that the electron withdrawing aryl substituent is directly related to the sensing ability/acidity of the squaramide protons and can be used to tune their anion recognition behavior. Moreover, given the interesting packing interactions observed in the crystal structure of $\mathbf{2}$ that involve classic hydrogen bonding, weaker non-classical $\mathrm{CH}$-based hydrogen bonding and $\pi-\pi$ stacking we envisage that squaramidoquinoxalines might be useful building blocks for anion-responsive supramolecular self-assembly formations. We are currently exploring these and other aspects of squaramides and the results will be reported in due course.

\section{Experimental section}

\section{General remarks}

${ }^{1} \mathrm{H}$ NMR spectra were recorded using a Bruker Avance III 500 at a frequency of $500.13 \mathrm{MHz}$, and are reported as parts per million (ppm) with DMSO- $d_{6}(\delta \mathrm{H} 2.50 \mathrm{ppm})$ as 
an internal reference. The data are reported as chemical shift $(\delta)$, multiplicity $(b r=$ broad, $s=$ singlet, $d=$ doublet, $\mathrm{t}=$ triplet, $\mathrm{m}=$ multiplet), coupling constant $(\mathrm{J}, \mathrm{Hz})$ and relative integral. ${ }^{13} \mathrm{C}$ NMR spectra were recorded using a Bruker Avance III 500 at a frequency of $125.76 \mathrm{MHz}$ and are reported as parts per million (ppm) with DMSO- $d_{6}$ ( $\delta \mathrm{H} 39.5 \mathrm{ppm})$ as an internal reference. High resolution ESI spectra were recorded on an Agilent 6310 LCMS TOF. Analytical TLC was performed using pre-coated silica gel plates (Merck Kieselgel 60 F254). Infrared absorption spectra were recorded on a Perkin Elmer Spectrum 100 FT-IR spectrometer using $\mathrm{KBr}$ disks. FT-IR are reported in wavenumbers $\left(\mathrm{cm}^{-1}\right)$. Commercial materials were used as received unless otherwise noted. Diethyl squarate were synthesised as previously described (16). Single-crystal $\mathrm{X}$-ray diffraction data was collected at $100 \mathrm{~K}$ on a Rigaku AFC12 goniometer equipped with an enhanced sensitivity (HG) Saturn 724 + detector mounted at the window of an FR-E + Superbright Mo- $\mathrm{K}_{\alpha}$ rotating anode generator $(\lambda=0.71075 \AA)$ with HF varimax optics (37). Unit cell parameters were refined against all data and an empirical absorption correction applied in CrysalisPro (38). The structure was solved by intrinsic phasing using ShelXT (39) and refined on $F_{O}{ }^{2}$ by ShelXL (39) using Olex2 (40). H-atoms were positioned geometrically and refined using a riding model except for $\mathrm{NH}$ protons which were located from electron density and freely refined. CCDC entry 1566512 contains the crystallographic data for the structure reported in this article.

\section{Spectroscopic binding studies}

Spectroscopic titrations were performed by additions of aliquots of the putative anionic guest as the tetrabutylammonium (TBA) salt, in a solution of the receptor $\left(1 \times 10^{-5} \mathrm{M}\right)$ in DMSO to a $1 \times 10^{-5} \mathrm{M}$ solution of the receptor in DMSO. Typically, 0 up to $0.12 \mathrm{M}$ of the anions were added to the solution. Both salt and receptor were dried under high vacuum prior to use. UV-Vis data was recorded using a Varian Cary 50 UV-Vis Spectrophotometer. The absorbance was recorded from 250 to $850 \mathrm{~nm}$. To determine association constants for the receptor-anion complexes, global analysis of the absorbance data was carried out using the open access BindFit software program $(33,41)$.

\section{NMR binding studies}

NMR titrations were performed by additions of aliquots of the putative anionic guest as the tetrabutylammonium (TBA) salt (0.15-0.2 M), in a solution of the receptor $\left(2.5 \times 10^{-3} \mathrm{M}\right)$ in DMSO- $d_{6}$ to a $2.5 \times 10^{-3} \mathrm{M}$ solution of the receptor in DMSO- $d_{6}$. Typically, up to 2 equivalents of the anion were added to the solution. Both salt and receptor were dried under high vacuum prior to use. ${ }^{1} \mathrm{H}$ NMR spectra were recorded on a Bruker Avance III 500 spectrometer at a frequency of $500.13 \mathrm{MHz}$ and calibrated to the residual protio solvent peak in DMSO- $d_{6}(\delta=2.50 \mathrm{ppm})$. Stack plots were made using TopSpin 3.2.

\section{Computational methods}

All electronic structure calculations have been performed with the Gaussian 09 (Revision D.01) program package (42). Unconstrained optimizations of groundstate geometries and subsequent analytical frequency calculations were carried out at DFT level using the M06-2X functional (43) in conjunction with the augcc-pVDZ basis set (44). Effects due to the presence of solvent were included by means of the Polarizable Continuum Model (IEF-PCM) (45), with parameters corresponding to those of dimethylsulfoxide $(\varepsilon=46.8)$. Non-electrostatic terms to solvation were calculated by invoking the SMD option (46). All stationary points were confirmed to be minima by the absence of imaginary modes in their vibrational spectra. Vertical transition energies to low-lying excited valence singlet states were computed with TD-DFT. For these calculations the B3LYP functional $(47,48)$ with a $6-311+G(2 d, p)$ basis $(49)$ on all atoms was selected. The SMD/IEF-PCM formalism described above was used to treat condensed phase effects. Natural Transition Orbitals (NTO) based on singular value decomposition of the 1-particle transition density were used to visualize dominant contributions to individual electronic excitations (50).

\section{General synthetic procedure}

The appropriately substituted aromatic diamine (1.2 equiv) was added to a stirred solution of diethyl squarate (1.0 equiv) and $\mathrm{Zn}(\mathrm{OTf})_{2}(0.2$ equiv.) in ethanol $(5 \mathrm{~mL})$. The reaction mixture was stirred at room temperature for $24 \mathrm{hr}$ before formation of a precipitate. The solid was collected by suction filtration and washed with $\mathrm{EtOH}$ and $\mathrm{Et}_{2} \mathrm{O}$ before being allowed to dry at room temp.

\section{(1) cyclobuta[b]quinoxaline-1,2(3H,8H)-dione}

1 was collected as as a beige solid. (0.708 $\mathrm{g}, 64 \%$ ), m.p. $\geq 300^{\circ} \mathrm{C} .{ }^{1} \mathrm{H}$ NMR $\left(500 \mathrm{MHz}\right.$, DMSO- $\left.d_{6}\right) \delta 9.99(\mathrm{~s}, 2 \mathrm{NH})$, $6.65(\mathrm{dd}, 2 \mathrm{H}, J=5.7 / 3.4 \mathrm{~Hz}), 6.36(\mathrm{dd}, 2 \mathrm{H}, J=5.5 / 3.6 \mathrm{~Hz}) ;{ }^{13} \mathrm{C}$ NMR (125 MHz, DMSO- $\left.d_{6}\right): 178.7,174.9,132.2,125.4,116.9$; HRMS (ESI): Calculated for $\mathrm{C}_{10} \mathrm{H}_{6} \mathrm{O}_{2} \mathrm{~N}_{2}[\mathrm{M}+\mathrm{H}]^{+}$, expected: 186.0428, observed: 186.0429, PPM:-0.64; vmax (film)/ cm $^{-1}: 3123,2955,2017,1913,1805,1790,1657,1614,1558$, $1478,1458,1358,1304,1245,1213,1180,1129,1075,1041$, $930,900,806,777,743,666$. 
(2) 5-nitrocyclobuta[b]quinoxaline-1,2(3H,8H)dione

2 was collected as a purple solid. (1.004 g, 74\%), m.p. $\geq 300^{\circ} \mathrm{C}$. ${ }^{1} \mathrm{H}$ NMR $\left(500 \mathrm{MHz}, \mathrm{DMSO}-d_{6}\right) \delta 10.55(\mathrm{~s}, \mathrm{NH}), 10.39(\mathrm{~s}, \mathrm{NH})$, $7.58(\mathrm{dd}, 1 \mathrm{H}, J=8.8 / 2.5 \mathrm{~Hz}), 7.01(\mathrm{~d}, 1 \mathrm{H}, J=2.5 \mathrm{~Hz}), 6.41$ $(\mathrm{d}, 1 \mathrm{H}, J=8.6 \mathrm{~Hz}) ;{ }^{13} \mathrm{C}$ NMR $\left(125 \mathrm{MHz}\right.$, DMSO- $\left.d_{6}\right): 179.6$, 178.5, 175.7, 174.8, 144.0, 139.8, 133.9, 122.7, 115.9, 110.4; HRMS (ESI): Calculated for $\mathrm{C}_{10} \mathrm{H}_{5} \mathrm{O}_{4} \mathrm{~N}_{3}[\mathrm{M}+\mathrm{H}]^{+}$, expected: 231.0282, observed: 231.028, PPM:0.71; vmax (film)/cm-1: 3572, 3141, 2974, 2020, 1870, 1794, 1665, 1632, 1583, 1529, $1487,1419,1322,1267,1247,1218,1202,1092,1073,945$, $883,861,837,803,788,745,670,646$.

\section{(3) 5-methoxycyclobuta[b]quinoxaline-1,2(3H,8H)- dione}

3 was collected as a brown solid. $(0.646 \mathrm{~g}, 97 \%), \mathrm{m} . \mathrm{p} . \geq 300^{\circ} \mathrm{C}$. ${ }^{1}$ H NMR $\left(500 \mathrm{MHz}, \mathrm{DMSO}-d_{6}\right) \delta 9.98(\mathrm{~s}, \mathrm{NH}), 9.96(\mathrm{~s}, \mathrm{NH})$, $6.31(\mathrm{~d}, 1 \mathrm{H}, J=8.6 \mathrm{~Hz}), 6.2(\mathrm{dd}, 1 \mathrm{H}, J=8.6 / 2.8 \mathrm{~Hz}), 6.00(\mathrm{~d}$, $1 \mathrm{H}, J=2.7 \mathrm{~Hz}), 3.60(\mathrm{~s}, 3 \mathrm{H}) ;{ }^{13} \mathrm{C}$ NMR $\left(125 \mathrm{MHz}\right.$, DMSO- $\left.d_{6}\right)$ : 179.1, 178.2, 174.6, 173.7, 157.2, 133.1, 125.1, 117.2, 107.5, 104.9, 56.0. HRMS (ESI): Calculated for $\mathrm{C}_{11} \mathrm{H}_{8} \mathrm{O}_{3} \mathrm{~N}_{2}[\mathrm{M}+\mathrm{H}]^{+}$, expected: 216.0547, observed: 216.0535, PPM:5.55; vmax (film)/(cm ${ }^{-1}:$ 3123, 2944, 1797, 1660, 1351, 1315, 1279, 1217, 1160, 1123, 1084, 1067, 1032, 941, 854, 788, 718, 672.

Crystal Data for $\mathrm{C}_{12} \mathrm{H}_{11} \mathrm{~N}_{3} \mathrm{O}_{5} \mathrm{~S}(\mathrm{M}=309.30 \mathrm{~g} / \mathrm{mol})$ : triclinic, space group P-1 (no. 2), $a=9.0082$ (8) $\AA, b=12.4212$ (10) $\AA, c=13.3063(9) \AA \AA \alpha=115.467(8)^{\circ}, \beta=96.055(7)^{\circ}, \gamma=$ 97.555(7) $, V=1310.5(2) \AA^{3}, Z=4, T=100.15 \mathrm{~K}, \mu\left(\right.$ MoK $\left._{\alpha}\right)=$ $0.274 \mathrm{~mm}^{-1}$, Dcalc $=1.568 \mathrm{~g} / \mathrm{cm}^{3}, 13,326$ reflections measured $\left(6.05^{\circ} \leq 2 \Theta \leq 51.998^{\circ}\right)$, 5137 unique $\left(R_{\text {int }}=0.0337\right.$, $\left.\mathrm{R}_{\text {sigma }}=0.0485\right)$ which were used in all calculations. The final $R_{1}$ was $0.0735(\mathrm{I}>2 \sigma(\mathrm{l}))$ and $w R_{2}$ was 0.1825 (all data).

\section{Acknowledgements}

Maynooth University are gratefully acknowledged for a Hume Scholarship to LM. JAK is grateful to the University of Southampton for support of this work.

\section{Disclosure statement}

No potential conflict of interest was reported by the authors.

\section{References}

(1) Gale, P.A.; Howe, E.N.W.; Wu, X. Chem 2016, 1, (3), 351-422.

(2) Evans, N.H.; Beer, P.D. Angew. Chem. Int. Ed. 2014, 53 (44), 11716-11754.

(3) Langton, M.J.; Serpell, C.J.; Beer, P.D. Angew. Chem. Int. Ed. 2016, 55 (6), 1974-1987.

(4) Jonathan L.; Sessler, P.G; Won-Seob C., Anion Receptor Chemistry; Stoddart J.F., Ed.; Monographs in Supramolecular Chemistry; Royal Society of Chemistry: Cambridge, 2006.
(5) Gunnlaugsson, T.; Glynn, M.; Tocci, G.M.; Kruger, P.E.; Pfeffer, F.M. Coord. Chem. Rev. 2006, 250 (23), 3094-3117.

(6) Zhou, Y.; Zhang, J.F.; Yoon, J. Chem. Rev. 2014, 114 (10), 5511-5571.

(7) Lee, S.; Yuen, K.K.Y.; Jolliffe, K.A.; Yoon, J. Chem. Soc. Rev. 2015, 44 (7), 1749-1762.

(8) Aletti, A.B.; Gillen, D.M.; Gunnlaugsson, T. Coord. Chem. Rev, 2017.

(9) Zhang, D.; Jiang, X.; Yang, H.; Su, Z.; Gao, E.; Martinez, A.; Gao, G. Chem. Commun. 2013, 49 (55), 6149-6151.

(10) Boyle, E.M.; Comby, S.; Molloy, J.K.; Gunnlaugsson, T. J. Org. Chem. 2013, 78 (17), 8312-8319.

(11) Blažek Bregović, V.; Basarić, N.; Mlinarić-Majerski, K. Coord. Chem. Rev. 2015, 295, 80-124.

(12) Pandurangan, K.; Kitchen, J.A.; Gunnlaugsson, T. Tet. Lett. 2013, 54 (22), 2770-2775.

(13) Kim, S.K.; Lee, H.G.; Vargas-Zúñiga, G.l.; Oh, J.H.; Lynch, V.M.; Lee, M.H.; Sessler, J.L. Supramol. Chem. 2017, 29 (9), 651-657.

(14) Lee, M.H.; Kim, J.S.; Sessler, J.L. Chem. Soc. Rev. 2015, 44 (13), 4185-4191.

(15) Elmes, R.B.P.; Jolliffe, K.A. Supramol. Chem. 2014, 27 (5-6), 321-328.

(16) Elmes, R.B.P.; Turner, P.; Jolliffe, K.A. Org. Lett. 2013, 15 (22), 5638-5641.

(17) Elmes, R.B.P.; Busschaert, N.; Czech, D.D.; Gale, P.A.; Jolliffe, K.A. Chem. Commun. 2015, 51 (50), 10107-10110.

(18) Elmes, R.B.P.; Yuen, K.Y. K.; Jolliffe, K.A. Chem. Eur. J. 2014, 20 (24), 7373-7380.

(19) Busschaert, N.; Elmes, R.B.P.; Czech, D.D.; Wu, X.; Kirby, I.L.; Peck, E.M.; Hendzel, K.D.; Shaw, S.K.; Chan, B.; Smith, B.D. Chem. Sci. 2014, 5 (9), 3617-3626.

(20) Qin, L.; Hartley, A.; Turner, P.; Elmes, R.B.P.; Jolliffe, K.A. Chem. Sci. 2016, 7 (7), 4563-4572.

(21) Cai, X.-J.; Li, Z.; Chen, W.-H. Bioorg. Med. Chem. Lett. 2017, 27 (9), 1999-2002.

(22) Edwards, S.J.; Valkenier, H.; Busschaert, N.; Gale, P.A.; Davis, A.P. Angew. Chem. Int. Ed. 2015, 54 (15), 4592-4596.

(23) Jin, C.; Zhang, M.; Wu, L.; Guan, Y.; Pan, Y.; Jiang, J.; Lin, C.; Wang, L. Chem. Commun. 2013, 49 (20), 2025-2027.

(24) Rostami, A.; Colin, A.; Li, X.Y.; Chudzinski, M.G.; Lough, A.J.; Taylor, M.S. J. Org. Chem. 2010, 75 (12), 3983-3992.

(25) Prohens, R.; Martorell, G.; Ballester, P.; Costa, A. Chem. Commun. 2001, 16, 1456-1457.

(26) Neus Piña, M.; Carmen Rotger, M.; Costa, A.; Ballester, P.; Deyà, P.M. Tet. Lett. 2004, 45 (19), 3749-3752.

(27) Soberats, B.; Martínez, L.; Sanna, E.; Sampedro, A.; Rotger, C.; Costa, A. Chem. Eur. J. 2012, 18 (24), 7533-7542.

(28) Davis, A.P.; Draper, S.M.; Dunne, G.; Ashton, P. Chem. Commun. 1999, 22, 2265-2266.

(29) Li, P.; Hu, X.; Dong, X.-Q.; Zhang, X. Molecules 2016, 21 (10), 1327.

(30) Amendola, V.; Bergamaschi, G.; Boiocchi, M.; Fabbrizzi, L.; Milani, M. Chem. Eur. J. 2010, 16 (14), 4368-4380.

(31) Jacquemin, D.; Perpète, E.A.; Scuseria, G.E.; Ciofini, I.; Adamo, C. J. Chem. Theory Comput. 2008, 4, (1), 123-135.

(32) Boiocchi, M.; Del Boca, L.; Gómez, D.E.; Fabbrizzi, L.; Licchelli, M.; Monzani, E. J. Am. Chem. Soc. 2004, 126 (50), 16507-16514.

(33) Thordarson, P. Chem. Soc. Rev. 2011, 40 (3), 1305-1323.

(34) Supramolecular.org.

(35) Niu, H.; Shu, Q.; Jin, S.; Li, B.; Zhu, J.; Li, L.; Chen, S. Spectrochim. Acta. A 2016, 153, 194-198. 
(36) Elmes, R.B.P.; Gunnlaugsson, T. Tet. Lett. 2010, 51 (31), 4082-4087.

(37) Coles, S.J.; Gale, P.A. Chem. Sci. 2012, 3, 683-689.

(38) CrysAlisPro 38.41, R.O.D., 2015).

(39) Sheldrick, G.M. Acta Crystallogr. Sec A Found Crystallogr 2008, 64, 112-122.

(40) Dolomanov, O.V.; Bourhis, L.J.; Gildea, R.J.; Howard, J.A.K.; Puschmann, H. J. Appl. Crystallogr. 2009, 42 (2), 339-341.

(41) Brynn Hibbert, D.; Thordarson, P. Chem. Commun. 2016, 52, 12792-12805.

(42) Frisch, M.J.; Trucks, G.W.; Schlegel, H.B.; Scuseria, G.E.; Robb, M.A.; Cheeseman, J.R.; Scalmani, G.; Barone, V.; Petersson, G.A.; Nakatsuji, H.; Li, X.; Caricato, M.; Marenich, A.; Bloino, J.; Janesko, B.G.; Gomperts, R.; Mennucci, B.; Hratchian, H.P.; Ortiz, J.V.; Izmaylov, A.F.; Sonnenberg, J.L.; WilliamsYoung, D.; Ding, F.; Lipparini, F.; Egidi, F.; Goings, J.; Peng, B.; Petrone, A.; Henderson, T.; Ranasinghe, D.; Zakrzewski, V.G.; Gao, J.; Rega, N.; Zheng, G.; Liang, W.; Hada, M.; Ehara, M.; Toyota, K.; Fukuda, R.; Hasegawa, J.; Ishida, M.; Nakajima, T.; Honda, Y.; Kitao, O.; Nakai, H.; Vreven, T.; Throssell, K.; Montgomery Jr., J.A.; Peralta, J.E.; Ogliaro, F.; Bearpark, M.;
Heyd, J.J.; Brothers, E.; Kudin, K.N.; Staroverov, V.N.; Keith, T.; Kobayashi, R.; Normand, J.; Raghavachari, K.; Rendell, A.; Burant, J.C.; lyengar, S.S.; Tomasi, J.; Cossi, M.; Millam, J.M.; Klene, M.; Adamo, C.; Cammi, R.; Ochterski, J.W.; Martin, R.L.; Morokuma, K.; Farkas, O.; Foresman, J.B.; Fox, D.J. Gaussian, Inc.: Wallingford CT, 2016.

(43) Zhao, Y.; Truhlar, D.G. Theor. Chem. Acc. 2008, 120 (1), 215241.

(44) Dunning, T.H.Jr. J. Chem. Phys. 1989, 90, (2), 1007-1023.

(45) Cossi, M.; Barone, V.; Cammi, R.; Tomasi, J. Chem. Phys. Lett. 1996, 255 (4), 327-335.

(46) Marenich, A.V.; Cramer, C.J.; Truhlar, D.G. J. Phys. Chem. B 2009, 113, (18), 6378-6396.

(47) Becke, A.D. J. Chem. Phys. 1993, 98 (7), 5648-5652.

(48) Stephens, P.J.; Devlin, F.J.; Chabalowski, C.F.; Frisch, M.J. J. Phys. Chem. 1994, 98 (45), 11623-11627.

(49) Krishnan, R.; Binkley, J.S.; Seeger, R.; Pople, J.A. J. Chem. Phys. 1980, 72 (1), 650-654.

(50) Martin, R.L. J. Chem. Phys. 2003, 118 (11), 4775-4777. 